\title{
WATER QUALITY ASSESSMENT AND MAPPING USING INVERSE DISTANCE WEIGHTED INTERPOLATION: A CASE OF RIVER KADUNA, NIGERIA
}

\author{
F. J. Ogbozige ${ }^{1,}$, D. B. Adie ${ }^{2}$ and U. A. Abubakar ${ }^{3}$

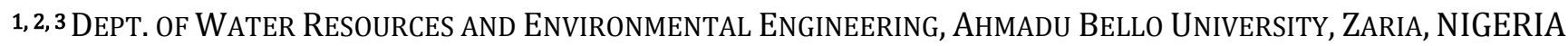 \\ E-mail addresses: ${ }^{1}$ engr.ogbozige@gmail.com, ${ }^{2}$ donadie2005@yahoo.com, ${ }^{3}$ uaabubakar@abu.edu.ng
}

\begin{abstract}
Several researchers have studied the water quality of the upper and lower stretches of River Kaduna with little on the middle stretch of the river. Besides, no work has ever been done on mapping the water quality of the said river. Hence, the middle stretch of River Kaduna was monitored for 12 months starting from June, 2016 to May, 2017, covering both rainy and dry seasons in 15 sampling locations to generate data for water quality mapping. However, eight water quality parameters were analyzed namely; temperature, turbidity, $p H$, dissolved oxygen, biochemical oxygen demand (BOD), chemical oxygen demand (COD), total nitrogen and total phosphorus using standard methods. Rainy season results were separated from dry season results and were used in mapping the water quality of the river for both seasons using ArcGIS 10.5. It was concluded that the water temperature of the river was within the permissible limit set by U.S. EPA during both seasons while the other water quality parameters apart from turbidity and $p H$ deteriorated more during dry season. In addition, COD and total phosphorus were found to be the only parameters that never met the requirement set by U.S. EPA throughout the sampling period irrespective of the sampling location and season. This is because the least measured concentrations of COD and total phosphorus were $35.34 \mathrm{mg} / \mathrm{l}$ and $0.109 \mathrm{mg} / \mathrm{l}$, respectively. It was recommended that farming activities at the river banks should be banned as the fertilizers used by farmers easily drain into the river and increase the phosphorus and COD concentrations.
\end{abstract}

Keywords: River, Kaduna, Interpolation, GIS Map, Water Quality.

\section{INTRODUCTION}

Studies have indicated that many rivers and streams particularly in developing countries are heavily polluted due to unregulated industrial and municipal wastewater discharges, as well as agricultural runoff [1, 2]. This assertion had earlier been noted by several researchers on River Kaduna who revealed that the water quality of the river is highly impaired due to anthropogenic activities [3 - 8]. However, none of these researchers developed a water quality map of the river as it flow downstream. Moreover, most of these researchers worked on the upper and lower sections of the river where there are lot of farming activities [9]. Conversely, the middle stretch of River Kaduna have been identified of having more municipal and industrial activities compared to the other sections of the river as it passes through the Kaduna city metropolis which is more of urban area $[10,11]$. In other word, there is likelihood of River Kaduna been more polluted at the middle stretch [12]. Hence, for proper planning and decisions on utilization of the water in middle stretch of River Kaduna, information on the water quality status, factors that influence the water quality as well as critical locations within the catchment area have to be identified. This could be achieved by monitoring the water quality of the river. However, monitoring the quality status of a river involves collection of water samples at various locations of the river and thereafter analyzing the physicochemical and bacteriological parameters. This will assist in identifying the sampling locations or areas along the river with high impairment level which will in turn aid in enforcement of standards and pollution control activities. Water samples are not usually collected at every point along a river but rather at identified sampling locations, therefore the challenge of ascertaining the quality status of the none sampling points in between sampling locations usually arise [13]. Interpolation being a process of estimating unknown values that falls between known values could be the solution for this challenge $[14,15]$. Hence, this research aimed at mapping the water quality of River Kaduna (middle stretch) via Inverse Distance Weighted (IDW)

\footnotetext{
* Corresponding author, tel: +234-903-749-4999
} 
interpolation method (a tool in ArcGIS 10.5) in order to estimating the water quality status of the none sampled points along the river.

\section{DESCRIPTION OF STUDY AREA}

Kaduna city is the capital of Kaduna State in North -Western Nigeria. River Kaduna is a tributary of the River Niger with its source from Kujama Hill in Plateau State and flows for $210 \mathrm{~km}$ before reaching Kaduna town. It crosses the city dividing it into north and south areas. Beyond Kaduna, the river flows for about $100 \mathrm{~km}$ into the Shiroro dam. It continues to flow for $100 \mathrm{~km}$ and finally discharges into River Niger at the northern shores of Pategi [16]. However, this study focused on the middle stretch of the river within Kaduna metropolis. That is, from Malali in Igabi Local Government Area (LGA) to the Railway Bridge at Rigasa in Rigasa LGA, covering a total distance of $32.7 \mathrm{~km}$. The study area which is located between latitudes $10^{\circ} 28^{\prime} 00^{\prime \prime}-10^{\circ} 36^{\prime} 00^{\prime \prime}$ North and longitude 070 21' 00" - 070 35' 00" East (ArcGIS 10.5), falls strategically inside four LGAs of Kaduna State. These are parts of Igabi, Chikun, Kaduna South and Kaduna North (Figure 1). The localities and communities that make up the study areas include; Malali Gabas, Ungwa Rimi, Ungwa Maigero, Narayi, Ungwa Pama, Bayanduse, Kabala, Barnawa, Ungwa Boro and Sabon Tasha. Others include Kigo road (new extension), Tudun Wada, Kakuri, Kudende, Ungwa Mu'azu, Rigasa, Nariya, Romi and Maigiginya.
The rainy season in River Kaduna and its environ is normally in the period of May to October, when the Inter-Tropical Convergence Zone has reached the northern part of Nigeria. The dry season, usually accompanied with high evaporation rate is from November to April when the North Easterly wind cover the whole of the northern part of Nigeria [17]. The mean annual rainfall can be as high as $2000 \mathrm{~mm}$ in wet years and as low as $500 \mathrm{~mm}$ in drought years, but with a long term average of $1000 \mathrm{~mm}$ while the mean annual temperature is about $24.5{ }^{\circ} \mathrm{C}$ [18]. The bedrock geology is predominantly metamorphic rocks of the Nigerian Basement Complex consisting of biotite gneisses and older granites. Generally, the soils and vegetation are typical red-brown to red-yellow tropical ferruginous soils and savannah grassland with scattered trees and woody shrubs. The soils in the upland areas are rich in red clay and sand but poor in organic matter. However, soils within the "fadama" areas are richer in kaolinitic clay and organic matter, very heavy and poorly drained characteristics of vertisols [5]. The population of Kaduna metropolis has shown a rapid increase of 10,653 to $1,570,331$ (estimated) from 1931 to 2006 [19]. This rapid increase in population resulted to rapid urbanization which consequently led to the transformation of River Kaduna floodplain into developed areas as most of the agricultural land have been converted to built-up areas.

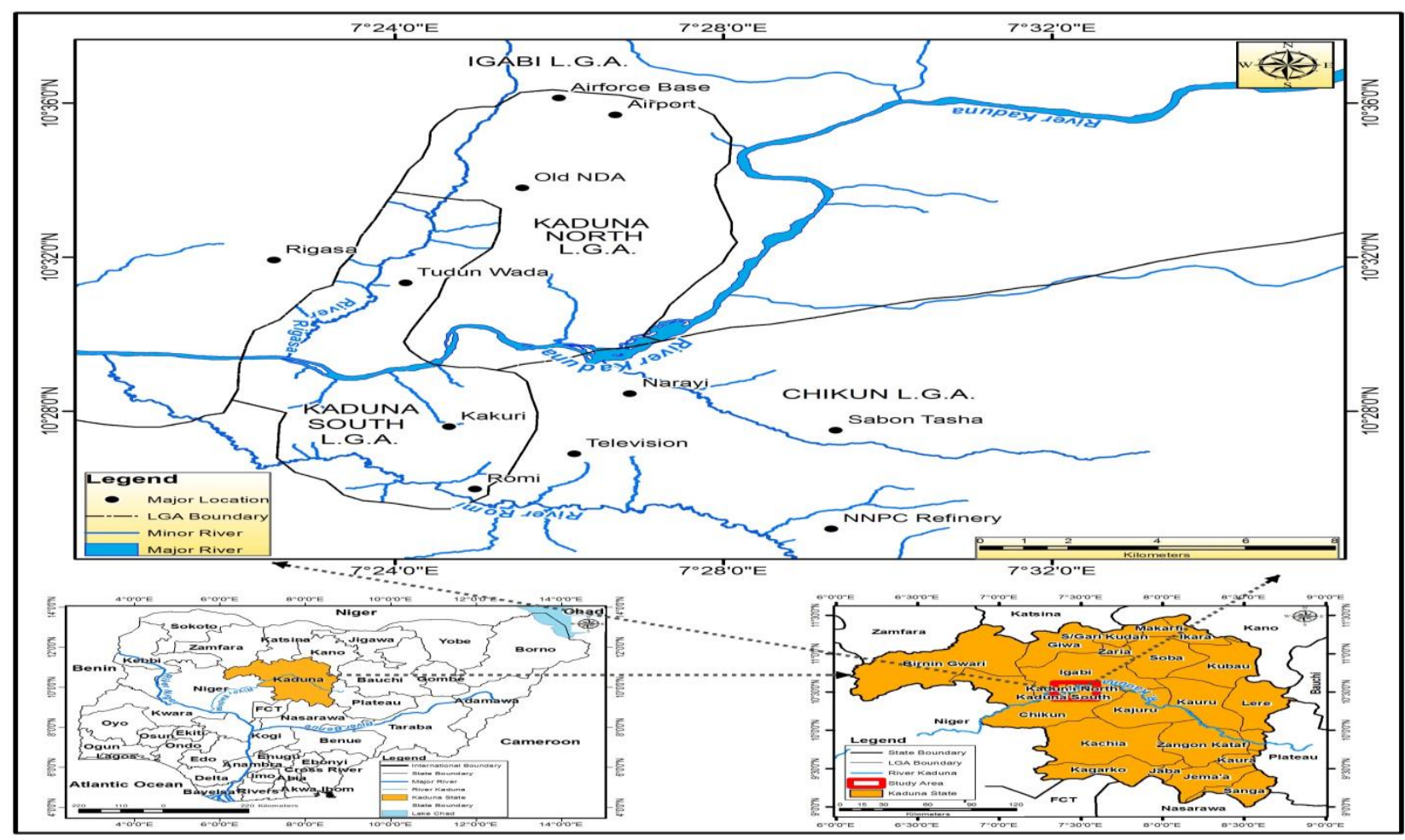

Figure 1: Map of River Kaduna within Kaduna metropolis. 


\section{MATERIALS AND METHOD}

\subsection{Materials}

A portable dissolved oxygen meter (DO STARTER300D, $\pm 1 \%$ made by OHAUS Corporation, USA) was used for the determination of dissolved oxygen while a Pocket-sized $\mathrm{pH}$ meter $\left(\mathrm{pHep}^{\circledR}, \pm 0.1\right.$ made by HANNA LTD, England) was used in determining $\mathrm{pH}$. Temperature was determined via a pocket-sized dissolved solids and conductivity meter with temperature compensation (TDS \& EC hold, $\pm 2 \%$ made by Griffin Company, USA). However, turbidity, total nitrogen and total phosphorus were analyzed by HACH $2100 \mathrm{~N}$ turbidimeter (made by HANNA, LTD, England), Kjeldahl auto distillation machine (Kjeltec $8200^{\mathrm{TM}}$ made by FOSS, Sweden) and Phosphorous meter (Colorimeter 257 made by Sherwood, USA) respectively. Glassware (BOD bottles, conical flasks, measuring cylinders, pipettes and burets) made by Kimax Company, England were used for titration during the determination of BOD and COD. In addition, a handheld Global Position System navigator (Etrex 20x) made by Garmin, USA was used in determining the geographical locations of the sampled points.

\subsection{Method}

\subsubsection{Sampling procedure and laboratory analysis}

The sampling was done monthly for a period of one year between June 2016 and May 2017; thus, covering two meteorological seasons. This sampling frequency and duration is in line with previous related works by other researchers [13, 20 - 23]. The grab sampling technique was employed in each sampling location. This was done by dipping high density polyethylene (HDPE) plastic bottles below the water surface at the center of the stream and ensuring that the mouth of the bottle faces the water current. Prior to sampling, the sample bottles were disinfected with methylated spirit and then thoroughly rinsed with the sample water before sample collection as recommended by the American Public Health Association [24]. The collected samples were stored in a cooler containing ice and delivered on the same day to the laboratory where they were refrigerated until analysis. However, temperature, dissolved oxygen (DO) and $\mathrm{pH}$ were determined in-situ. The methods employed in analyzing the water quality parameters are shown in Table 1. It should be noted that during the twelve month sampling period, a single water sample was collected at each sampling location as it's in agreement with previous water quality related researches $[13,20$, 23].
Table 1: Parameters and standard test methods for analyzing water quality of samples [25]

\begin{tabular}{ll}
\hline Parameter & Method \\
\hline Temperature & Thermistor \\
Turbidity & Turbidimeter \\
pH & Electrometric (pH meter) \\
DO & Electrometric (DO meter) \\
BOD $_{5}$ & $\begin{array}{l}\text { Incubation technique with DO } \\
\text { determination by DO meter }\end{array}$ \\
COD & Reflux distillation, followed by \\
& titrimetric \\
Total Nitrogen & Digestion, followed by distillation \\
Total & and titrimetric \\
Phosphorous & Digestion, followed by colorimetric \\
\hline
\end{tabular}

\subsubsection{Mapping of Water Quality}

As at the period this research was conducted, the latest version of the software used in mapping the water quality (ArcGIS) was version 10.5. Hence, Inverse Distance Weighted Interpolation (IDW) method of the spatial analyst extension in the ArcGIS 10.5 was used in mapping the water quality parameters within the catchment area. This is because Inverse Distance Weighted interpolation (IDW) assumes that the nearer a sample point is to the cell whose value is to be estimated, the more closely the cell's value will resemble the sample point's value [14]. In other words, the principle underlying IDW is the Waldo Tobler's first law of Geography which states that "everything is related to everything else, but near things are more related than distant things".

IDW uses linear combination of weights at known points to estimate unknown location values [14]. That is, values at unknown locations $\hat{Z}\left(S_{0}\right)$ were determined by the weighting value $\lambda_{i}\left(S_{0}\right)$ and values at known locations $Z\left(S_{i}\right)$ expressed mathematically as shown in Equation (1), [14].

$$
\hat{Z}\left(S_{0}\right)=\sum_{i=1}^{n} \lambda_{i}\left(S_{0}\right) \cdot Z\left(S_{i}\right)
$$

However, the weights $\lambda_{i}\left(S_{0}\right)$ were estimated through inverse distance from all points to the new points by applying Equation (2), [14].

$$
\lambda_{i}\left(S_{0}\right)=\frac{\frac{1}{\beta d\left(S_{0}, S_{1}\right)}}{\sum_{i=0}^{n} \frac{1}{\beta d\left(S_{0}, S_{1}\right)}} ; \beta>1
$$

Where: $\lambda_{i}$ is the weight for neighbor $i$ (the sum of weights must be unity to ensure an unbiased interpolator), $\boldsymbol{d}\left(\boldsymbol{S}_{\mathbf{0}}, \boldsymbol{S}_{\mathbf{1}}\right)$ is the distance from the new point to a known sample point, $\boldsymbol{\beta}$ is the coefficient used to adjust the weights, and $\boldsymbol{n}$ is the total number of points in the neighbourhood analysis. 
All the measured points (water quality data) were used in the calculation of each interpolation cell (water quality grid). A feature dataset (river network) was used for the mask. Only cells that falls within the specified shape of the feature dataset (river network) received the values of the first input raster (water quality grid) on the output raster (water quality result). The output raster is the extraction of the cells of the water quality grid (input raster) that corresponds to the routes defined by the mask. These illustrations for IDW method of mapping in ArcGIS 10.5 are shown in Figures 2 and 3.

Seasonal classifications were based on dry season (November, December, January, February, March and
April) and rainy season (May, June, July, August, September and October) with the map legend according to the data range for the season. For each examined parameter, the seasonal mean value during both seasons (dry and rainy) was computed and used as weights in mapping the river in terms of such parameter via IDW.

\section{RESULTS AND DISCUSSION}

The results of the physicochemical parameters analyzed in all the sampling locations during the dry season and rainy season are shown in Tables 2 and 3, respectively.

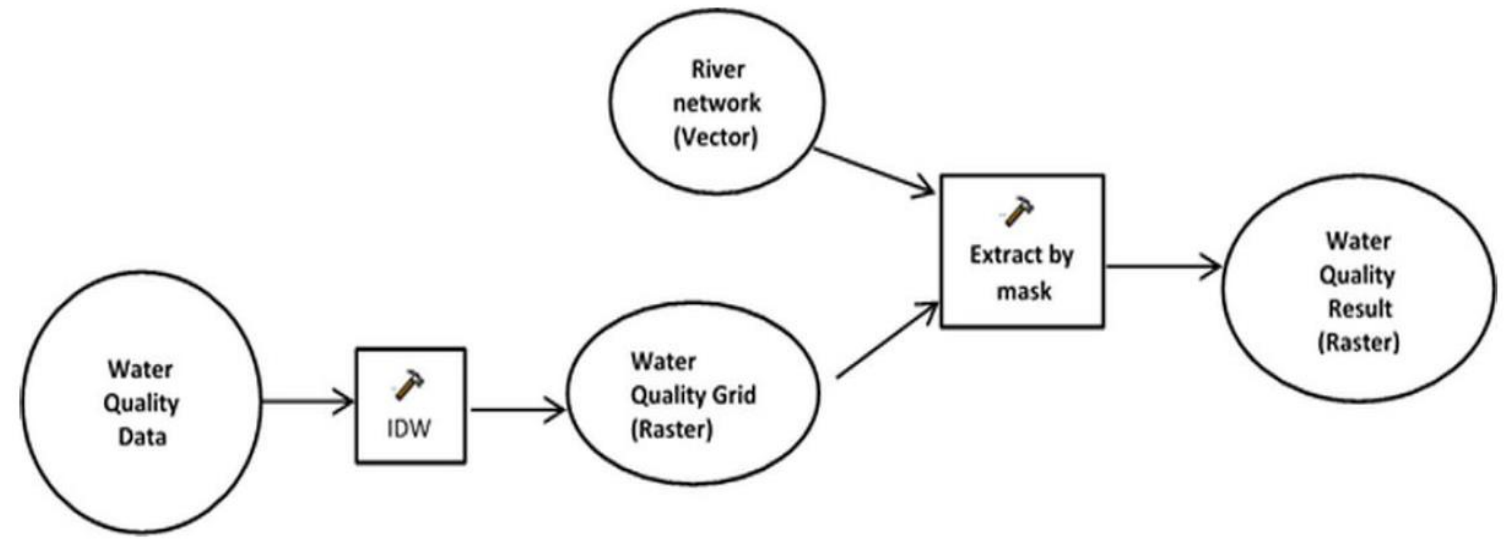

Figure 2: Flow chart of IDW mapping procedure in ArcGIS 10.5

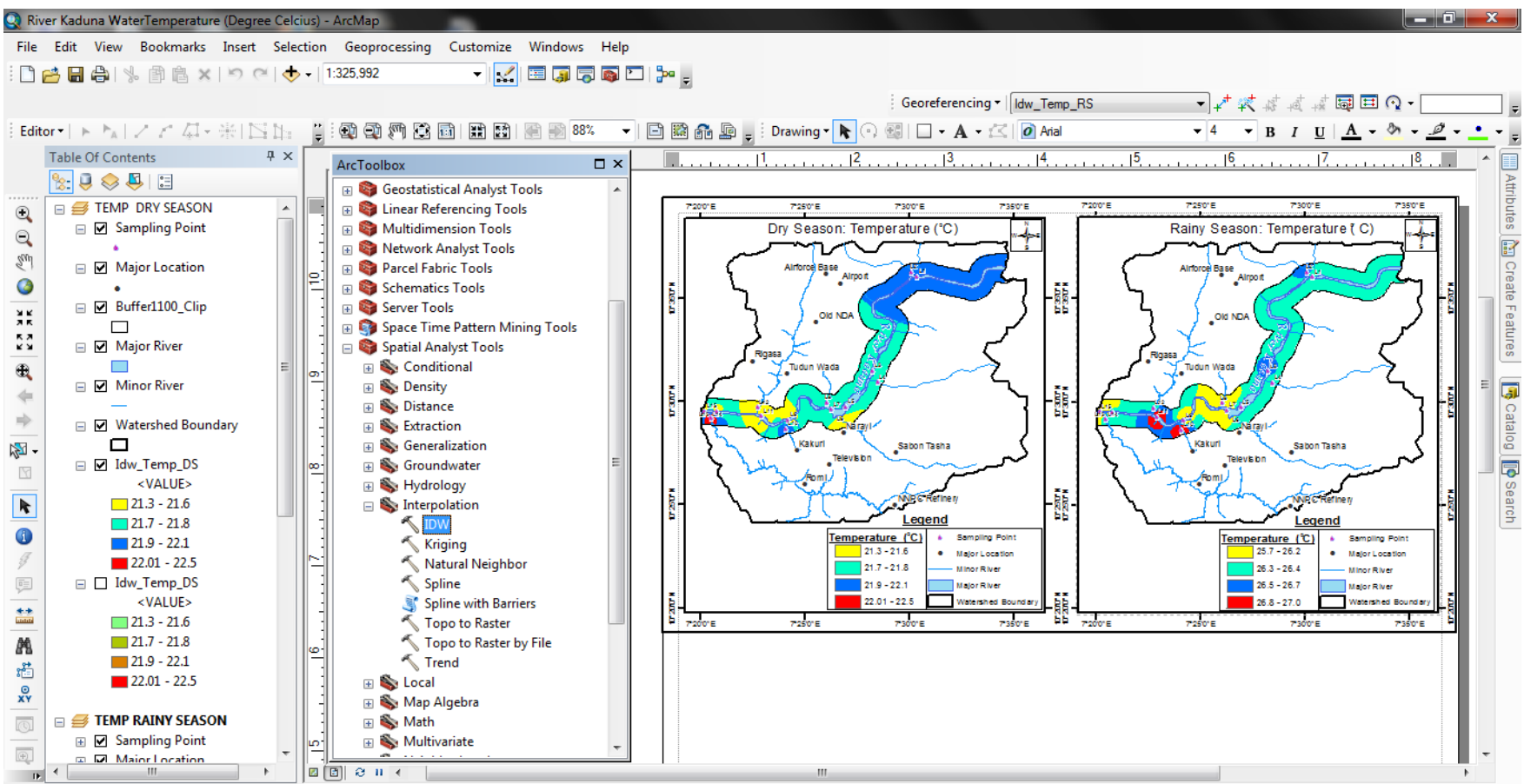

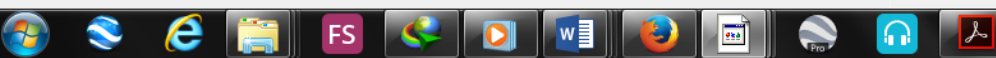


Water Quality Assessment ANd Mapping using InVerse Distance Weighted InTERPolation: A CaSe.... F. J. Ogbozige, et al

Table 2: Water quality results across sampling locations during dry season

\begin{tabular}{|c|c|c|c|c|c|c|c|c|c|c|}
\hline $\begin{array}{l}\text { Location } \\
\text { Code }\end{array}$ & $\begin{array}{l}\text { Location } \\
\text { Name }\end{array}$ & $\begin{array}{c}\text { Geographical } \\
\text { Coordinate }\end{array}$ & $\begin{array}{c}\text { Temperature } \\
\left({ }^{\circ} \mathrm{C}\right)\end{array}$ & $\begin{array}{l}\text { Turbidity } \\
\text { (NTU) }\end{array}$ & $\mathrm{pH}$ & $\begin{array}{c}\mathrm{DO} \\
(\mathrm{mg} / \mathrm{l})\end{array}$ & $\begin{array}{l}\mathrm{BOD}_{5} \\
(\mathrm{mg} / \mathrm{l})\end{array}$ & $\begin{array}{l}\mathrm{COD} \\
(\mathrm{mg} / \mathrm{l})\end{array}$ & $\begin{array}{c}\mathrm{TN} \\
(\mathrm{mg} / \mathrm{l})\end{array}$ & $\begin{array}{c}\mathrm{TP} \\
(\mathrm{mg} / \mathrm{l})\end{array}$ \\
\hline L1 & Malali & $\begin{array}{l}10^{\circ} 36^{\prime} 3.09^{\prime \prime} \mathrm{N} \\
7^{\circ} 30^{\prime} 21.91^{\prime \prime} \mathrm{E}\end{array}$ & $22.0 \pm 0.02$ & $18.365 \pm 0.05$ & $7.5 \pm 0.1$ & $6.19 \pm 0.01$ & $0.63 \pm 0.01$ & $43.02 \pm 0.1$ & $1.60 \pm 0.01$ & $0.234 \pm 0.05$ \\
\hline L2 & Kwarau & $\begin{array}{l}10^{\circ} 36^{\prime} 16.96 " \mathrm{~N} \\
7^{\circ} 30^{\prime} 5.43^{\prime \prime} \mathrm{E}\end{array}$ & $22.0 \pm 0.02$ & $5.990 \pm 0.05$ & $7.3 \pm 0.1$ & $4.89 \pm 0.01$ & $0.77 \pm 0.01$ & $44.56 \pm 0.1$ & $1.33 \pm 0.01$ & $0.194 \pm 0.05$ \\
\hline L3 & NNPC & $\begin{array}{l}10^{\circ} 31 ' 29.23 " \mathrm{~N} \\
7^{\circ} 28^{\prime} 14.04 " \mathrm{E}\end{array}$ & $21.7 \pm 0.02$ & $2.927 \pm 0.05$ & $7.5 \pm 0.1$ & $6.18 \pm 0.01$ & $1.93 \pm 0.01$ & $60.97 \pm 0.1$ & $1.23 \pm 0.01$ & $0.179 \pm 0.05$ \\
\hline L4 & Kuyi & $\begin{array}{l}10^{\circ} 30^{\prime} 56.02 " \mathrm{~N} \\
7^{\circ} 28^{\prime} 28.84 " \mathrm{E}\end{array}$ & $21.7 \pm 0.02$ & $6.223 \pm 0.05$ & $7.1 \pm 0.1$ & $4.50 \pm 0.01$ & $1.47 \pm 0.01$ & $49.88 \pm 0.1$ & $1.34 \pm 0.01$ & $0.195 \pm 0.05$ \\
\hline L5 & Barnawa & $\begin{array}{l}10^{\circ} 29^{\prime} 44.46 " \mathrm{~N}, \\
7^{\circ} 26^{\prime} 56.86 " \mathrm{E}\end{array}$ & $21.8 \pm 0.02$ & $6.454 \pm 0.05$ & $7.5 \pm 0.1$ & $4.96 \pm 0.01$ & $1.79 \pm 0.01$ & $51.05 \pm 0.1$ & $1.34 \pm 0.01$ & $0.196 \pm 0.05$ \\
\hline L6 & Kutimbi & $7^{\circ} 27^{\prime} 6.71 " \mathrm{E}$ & $21.3 \pm 0.02$ & $4.696 \pm 0.05$ & $6.8 \pm 0.1$ & $3.30 \pm 0.01$ & $2.36 \pm 0.01$ & $56.80 \pm 0.1$ & $1.31 \pm 0.01$ & $0.186 \pm 0.05$ \\
\hline L7 & Living Faith & $\begin{array}{l}10^{\circ} 29^{\prime} 36.82 " \mathrm{~N} \\
7^{\circ} 26^{\prime} 16.25^{\prime \prime} \mathrm{E}\end{array}$ & $21.7 \pm 0.02$ & $3.363 \pm 0.05$ & $7.5 \pm 0.1$ & $4.20 \pm 0.01$ & $2.18 \pm 0.01$ & $65.05 \pm 0.1$ & $1.24 \pm 0.01$ & $0.180 \pm 0.05$ \\
\hline L8 & Kigo & $\begin{array}{l}10^{\circ} 29^{\prime} 57.44^{\prime \prime} \mathrm{N} \\
7^{\circ} 26^{\prime} 3.32 " \mathrm{E}\end{array}$ & $21.8 \pm 0.02$ & $1.258 \pm 0.05$ & $7.0 \pm 0.1$ & $3.19 \pm 0.01$ & $2.52 \pm 0.01$ & $74.08 \pm 0.1$ & $1.70 \pm 0.01$ & $0.216 \pm 0.05$ \\
\hline L9 & $\begin{array}{l}\text { Down } \\
\text { Quarters }\end{array}$ & $\begin{array}{l}10^{\circ} 29^{\prime} 6.80 " \mathrm{~N} \\
7^{\circ} 24^{\prime} 13.53 " \mathrm{E}\end{array}$ & $21.5 \pm 0.02$ & $3.552 \pm 0.05$ & $7.3 \pm 0.1$ & $3.90 \pm 0.01$ & $2.40 \pm 0.01$ & $63.91 \pm 0.1$ & $1.24 \pm 0.01$ & $0.181 \pm 0.05$ \\
\hline L10 & Breweries & $\begin{array}{l}10^{\circ} 28^{\prime} 40.07^{\prime \prime} \mathrm{N} \\
7^{\circ} 24^{\prime} 7.42^{\prime \prime} \mathrm{E}\end{array}$ & $22.0 \pm 0.02$ & $1.572 \pm 0.05$ & $9.2 \pm 0.1$ & $2.76 \pm 0.01$ & $2.16 \pm 0.01$ & $71.09 \pm 0.1$ & $1.60 \pm 0.01$ & $0.233 \pm 0.05$ \\
\hline L11 & $\begin{array}{l}\text { Ungwa } \\
\text { Mu'Azu }\end{array}$ & $\begin{array}{l}10^{\circ} 29^{\prime} 17.15^{\prime \prime} \mathrm{N} \\
7^{\circ} 22^{\prime} 56.89^{\prime \prime} \mathrm{E}\end{array}$ & $21.5 \pm 0.02$ & $3.729 \pm 0.05$ & $7.6 \pm 0.1$ & $3.66 \pm 0.01$ & $2.15 \pm 0.01$ & $58.66 \pm 0.1$ & $1.25 \pm 0.01$ & $0.182 \pm 0.05$ \\
\hline L12 & Rigasa & $\begin{array}{l}10^{\circ} 29^{\prime} 42.63^{\prime \prime} \mathrm{N}, \\
7^{\circ} 22^{\prime} 45.92^{\prime \prime} \mathrm{E}\end{array}$ & $21.5 \pm 0.02$ & $3.174 \pm 0.05$ & $7.1 \pm 0.1$ & $3.60 \pm 0.01$ & $2.53 \pm 0.01$ & $64.45 \pm 0.1$ & $1.45 \pm 0.01$ & $0.212 \pm 0.05$ \\
\hline L13 & Maigiginya & $\begin{array}{l}10^{\circ} 29^{\prime} 30.84^{\prime \prime} \mathrm{N}, \\
7^{\circ} 20^{\prime} 48.66 " \mathrm{E}\end{array}$ & $21.5 \pm 0.02$ & $11.724 \pm 0.05$ & $7.6 \pm 0.1$ & $4.15 \pm 0.01$ & $0.75 \pm 0.01$ & $46.01 \pm 0.1$ & $1.46 \pm 0.01$ & $0.213 \pm 0.05$ \\
\hline L14 & Romi & $\begin{array}{l}10^{\circ} 29^{\prime} 10.65 " \mathrm{~N} \\
7^{\circ} 20^{\prime} 31.50^{\prime \prime} \mathrm{E}\end{array}$ & $22.5 \pm 0.02$ & $6.217 \pm 0.05$ & $7.7 \pm 0.1$ & $4.43 \pm 0.01$ & $1.53 \pm 0.01$ & $50.89 \pm 0.1$ & $1.33 \pm 0.01$ & $0.195 \pm 0.05$ \\
\hline L15 & $\begin{array}{l}\text { Railway } \\
\text { Bridge }\end{array}$ & $\begin{array}{l}10^{\circ} 29 ' 31.67 " \mathrm{~N} \\
7^{\circ} 20^{\prime} 13.77^{\prime \prime} \mathrm{E}\end{array}$ & $21.5 \pm 0.02$ & $14.537 \pm 0.05$ & $7.6 \pm 0.1$ & $4.16 \pm 0.01$ & $0.31 \pm 0.01$ & $42.50 \pm 0.1$ & $1.52 \pm 0.01$ & $0.222 \pm 0.05$ \\
\hline \multicolumn{3}{|c|}{ U.S EPA Permissible limit } & $<40.0$ & $\leq 5.0$ & $6.5-8.5$ & $\geq 5.0$ & $\leq 2.0$ & $\leq 20.0$ & $\leq 1.0$ & $\leq 0.1$ \\
\hline
\end{tabular}

Table 3: Water quality results across sampling locations during rainy season

\begin{tabular}{|c|c|c|c|c|c|c|c|c|c|c|}
\hline $\begin{array}{l}\text { Location } \\
\text { Code }\end{array}$ & $\begin{array}{l}\text { Location } \\
\text { Name }\end{array}$ & $\begin{array}{c}\text { Geographical } \\
\text { Coordinate }\end{array}$ & $\begin{array}{c}\text { Temperature } \\
\left({ }^{\circ} \mathrm{C}\right)\end{array}$ & $\begin{array}{l}\text { Turbidity } \\
\text { (NTU) }\end{array}$ & $\mathrm{pH}$ & $\begin{array}{c}\mathrm{DO} \\
(\mathrm{mg} / \mathrm{l})\end{array}$ & $\begin{array}{l}\mathrm{BOD}_{5} \\
(\mathrm{mg} / \mathrm{l})\end{array}$ & $\begin{array}{l}\text { COD } \\
(\mathrm{mg} / \mathrm{l})\end{array}$ & $\begin{array}{c}\mathrm{TN} \\
(\mathrm{mg} / \mathrm{l})\end{array}$ & $\begin{array}{c}\mathrm{TP} \\
(\mathrm{mg} / \mathrm{l})\end{array}$ \\
\hline L1 & Malali & $\begin{array}{l}10^{\circ} 36^{\prime} 3.09 " \mathrm{~N} \\
7^{\circ} 30^{\prime} 21.91^{\prime \prime} \mathrm{E}\end{array}$ & $26.2 \pm 0.02$ & $62.911 \pm 0.05$ & $7.0 \pm 0.1$ & $7.78 \pm 0.01$ & $0.51 \pm 0.01$ & $35.57 \pm 0.1$ & $0.98 \pm 0.01$ & $0.142 \pm 0.05$ \\
\hline L2 & Kwarau & $\begin{array}{l}10^{\circ} 36^{\prime} 16.96 " \mathrm{~N}, \\
7^{\circ} 30^{\prime} 5.43^{\prime \prime} \mathrm{E}\end{array}$ & $26.5 \pm 0.02$ & $59.068 \pm 0.05$ & $7.0 \pm 0.1$ & $6.35 \pm 0.01$ & $0.59 \pm 0.01$ & $36.87 \pm 0.1$ & $0.81 \pm 0.01$ & $0.118 \pm 0.05$ \\
\hline L3 & NNPC & $\begin{array}{l}10^{\circ} 31 ' 29.23 " \mathrm{~N}, \\
7^{\circ} 28^{\prime} 14.04 " \mathrm{E}\end{array}$ & $26.5 \pm 0.02$ & $120.896 \pm 0.05$ & $7.1 \pm 0.1$ & $7.74 \pm 0.01$ & $1.55 \pm 0.01$ & $50.44 \pm 0.1$ & $0.75 \pm 0.01$ & $0.109 \pm 0.05$ \\
\hline L4 & Kuyi & $\begin{array}{l}10^{\circ} 30^{\prime} 56.02 " \mathrm{~N} \\
7^{\circ} 28^{\prime} 28.84^{\prime \prime} \mathrm{E}\end{array}$ & $26.2 \pm 0.02$ & $66.661 \pm 0.05$ & $6.7 \pm 0.1$ & $6.10 \pm 0.01$ & $1.08 \pm 0.01$ & $41.27 \pm 0.1$ & $0.81 \pm 0.01$ & $0.119 \pm 0.05$ \\
\hline L5 & Barnawa & $\begin{array}{l}10^{\circ} 29^{\prime} 44.46 " \mathrm{~N}, \\
7^{\circ} 26^{\prime} 56.86^{\prime \prime} \mathrm{E} \\
10^{\circ} 28^{\prime} 53.12^{\prime \prime} \mathrm{N}\end{array}$ & $26.3 \pm 0.02$ & $64.768 \pm 0.05$ & $7.1 \pm 0.1$ & $6.68 \pm 0.01$ & $1.33 \pm 0.01$ & $42.38 \pm 0.1$ & $0.82 \pm 0.01$ & $0.120 \pm 0.05$ \\
\hline L6 & Kutimbi & $7^{\circ} 27^{\prime} 6.711^{\prime \prime E}$ & $26.3 \pm 0.02$ & $76.484 \pm 0.05$ & $6.4 \pm 0.1$ & $4.36 \pm 0.01$ & $1.94 \pm 0.01$ & $46.99 \pm 0.1$ & $0.71 \pm 0.01$ & $0.110 \pm 0.05$ \\
\hline
\end{tabular}




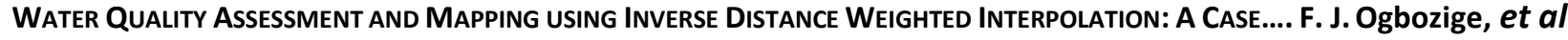

\begin{tabular}{|c|c|c|c|c|c|c|c|c|c|c|}
\hline L7 & Living Faith & $\begin{array}{l}10^{\circ} 29^{\prime} 36.82 " \mathrm{~N} \\
7^{\circ} 26^{\prime} 16.25^{\prime \prime} \mathrm{E}\end{array}$ & $26.0 \pm 0.02$ & $88.077 \pm 0.05$ & $7.0 \pm 0.1$ & $6.55 \pm 0.01$ & $1.80 \pm 0.01$ & $53.81 \pm 0.1$ & $0.75 \pm 0.01$ & $0.110 \pm 0.05$ \\
\hline L8 & Kigo & $\begin{array}{l}10^{\circ} 29^{\prime} 57.44 " \mathrm{~N} \\
7^{\circ} 26^{\prime} 3.32 \mathrm{E} \mathrm{E}\end{array}$ & $25.8 \pm 0.02$ & $151.38 \pm 0.05$ & $6.3 \pm 0.1$ & $4.31 \pm 0.01$ & $1.98 \pm 0.01$ & $61.46 \pm 0.1$ & $0.93 \pm 0.01$ & $0.123 \pm 0.05$ \\
\hline L9 & $\begin{array}{l}\text { Down } \\
\text { Quarters }\end{array}$ & $\begin{array}{l}10^{\circ} 29^{\prime} 6.80^{\prime \prime} \mathrm{N} \\
7^{\circ} 24^{\prime} 13.53^{\prime \prime} \mathrm{E}\end{array}$ & $25.8 \pm 0.02$ & $88.062 \pm 0.05$ & $6.9 \pm 0.1$ & $6.59 \pm 0.01$ & $1.78 \pm 0.01$ & $52.87 \pm 0.1$ & $0.76 \pm 0.01$ & $0.111 \pm 0.05$ \\
\hline L10 & Breweries & $\begin{array}{l}10^{\circ} 28^{\prime} 40.07^{\prime \prime} \mathrm{N} \\
7^{\circ} 24^{\prime} 7.42^{\prime \prime} \mathrm{E}\end{array}$ & $27.0 \pm 0.02$ & $134.69 \pm 0.05$ & $8.7 \pm 0.1$ & $3.97 \pm 0.01$ & $2.27 \pm 0.01$ & $58.81 \pm 0.1$ & $0.87 \pm 0.01$ & $0.127 \pm 0.05$ \\
\hline L11 & $\begin{array}{l}\text { Ungwa } \\
\text { Mu'Azu }\end{array}$ & $\begin{array}{l}10^{\circ} 29^{\prime} 17.15^{\prime \prime} \mathrm{N} \\
7^{\circ} 22^{\prime} 56.89^{\prime \prime} \mathrm{E}\end{array}$ & $26.9 \pm 0.02$ & $86.440 \pm 0.05$ & $6.9 \pm 0.1$ & $6.42 \pm 0.01$ & $1.59 \pm 0.01$ & $48.58 \pm 0.1$ & $0.76 \pm 0.01$ & $0.112 \pm 0.05$ \\
\hline L12 & Rigasa & $\begin{array}{l}10^{\circ} 29^{\prime} 42.63^{\prime \prime} \mathrm{N} \\
7^{\circ} 22^{\prime} 45.92^{\prime \prime} \mathrm{E}\end{array}$ & $26.2 \pm 0.02$ & $89.599 \pm 0.05$ & $6.4 \pm 0.1$ & $4.29 \pm 0.01$ & $1.97 \pm 0.01$ & $53.37 \pm 0.1$ & $0.79 \pm 0.01$ & $0.116 \pm 0.05$ \\
\hline L13 & Maigiginya & $\begin{array}{l}10^{\circ} 29^{\prime} 30.84^{\prime \prime} \mathrm{N} \\
7^{\circ} 20^{\prime} 48.66^{\prime \prime} \mathrm{E}\end{array}$ & $26.2 \pm 0.02$ & $60.468 \pm 0.05$ & $6.9 \pm 0.1$ & $7.03 \pm 0.01$ & $0.45 \pm 0.01$ & $38.10 \pm 0.1$ & $0.89 \pm 0.01$ & $0.130 \pm 0.05$ \\
\hline L14 & Romi & $\begin{array}{l}10^{\circ} 29^{\prime} 10.65^{\prime \prime N}, \\
7^{\circ} 20^{\prime} 31.50^{\prime \prime} \mathrm{E}\end{array}$ & $26.3 \pm 0.02$ & $68.198 \pm 0.05$ & $7.4 \pm 0.1$ & $6.33 \pm 0.01$ & $1.07 \pm 0.01$ & $42.32 \pm 0.1$ & $0.81 \pm 0.01$ & $0.118 \pm 0.05$ \\
\hline L15 & $\begin{array}{l}\text { Railway } \\
\text { Bridge }\end{array}$ & $\begin{array}{l}10^{\circ} 29^{\prime} 31.67 " \mathrm{~N} \\
7^{\circ} 20^{\prime} 13.77^{\prime \prime} \mathrm{E}\end{array}$ & $25.7 \pm 0.02$ & $44.308 \pm 0.05$ & $7.0 \pm 0.1$ & $7.01 \pm 0.01$ & $0.18 \pm 0.01$ & $35.34 \pm 0.1$ & $0.93 \pm 0.01$ & $0.135 \pm 0.05$ \\
\hline \multicolumn{3}{|c|}{ U.S EPA Permissible limit } & $<40.0$ & $\leq 5.0$ & $6.5-8.5$ & $\geq 5.0$ & $\leq 2.0$ & $\leq 20.0$ & $\leq 1.0$ & $\leq 0.1$ \\
\hline
\end{tabular}

\subsection{Temperature}

The mean water temperature of the river during the dry season ranged between $21.3 \pm 0.02{ }^{\circ} \mathrm{C}$ to $22.5 \pm 0.02$ ${ }^{\circ} \mathrm{C}$ respectively, corresponding to sampling locations L6 (Kutimbi) and L14 (Romi) as could be seen in Table 2. On the other hand, Table 3 revealed that the mean water temperature during the rainy season ranged between $25.7 \pm 0.02{ }^{\circ} \mathrm{C}$ to $27 \pm 0.02{ }^{\circ} \mathrm{C}$, corresponding to sampling locations L15 (Railway Bridge) and L10 (Breweries) in that order. In other words, the water temperatures recorded during the rainy season were slightly higher than those obtained during the dry season, irrespective of the sampling location. This could be attributed to the fact that, atmospheric humidity is lower during the dry season (especially harmattan period) than the rainy season [26]. This might have caused more water molecules on the surface of River Kaduna or sampling locations to have evaporated during dry season than rainy season [26, 27]. This higher evaporation rate of the dry season resulted to the lower water temperature observed (cooling effect of evaporation) during the dry season [28]. The higher water temperature values recorded during the rainy season compared to the dry season is in accordance with an earlier work conducted in the river [3]. However, the water temperatures during both seasons in all the sampling locations were within the permissible limit set by U.S EPA $\left(<40^{\circ} \mathrm{C}\right)$. The water temperatures in the non-sampled locations during both seasons could be seen in Figure 4 as mapped using ArcGIS 10.5 .

\subsection{Turbidity}

The turbidity values recorded during the rainy season were excessively higher than those observed during the dry season (see Tables 2 and 3). This is because the mean values of turbidity for the dry season ranged between $1.258 \pm 0.05 \mathrm{NTU}$ (at L8) to $18.365 \pm 0.05 \mathrm{NTU}$ (at L1) compared to that of the rainy season which ranged between $\quad 44.308 \pm 0.05 \mathrm{NTU}$ (at L15) to $151.383 \pm 0.05 \mathrm{NTU}$ (at L8). In other words, the turbidity of the river during the rainy season in all the sampling locations were excessively higher than the permissible limit for river protection (5.0 NTU). This might be as a result of water runoff. Runoff carries clay particles, silt and sand washings, organic and biological sludge etc. from agricultural fields as well as from drainages and unpaved urban land in which the soil is easily washed. This runoff with its associated debris finally flows into the river thereby causing the river water to be highly turbid during the rainy season. Conversely, the presence of turbidity (although small) during the dry season despite the absence of runoff might be caused by in-stream activities. During dry season, river depths are usually shallow due to less water in the rivers hence, in-stream activities such as watering of animals by nomads as well as rowing of canoes by fishermen might have stirred up bottom sediments which consequently made the water turbid. 
The extremely higher turbidity values recorded during the rainy season compared to the dry season is in agreement with past related literatures $[29,30]$. The turbidity level of the river in relation to areas and towns that drains to the river are mapped and shown in Figure 5.

\section{$4.3 \mathrm{pH}$}

The mean dry season $\mathrm{pH}$ values in all the sampling locations were within the permissible range set by U.S. EPA (6.5 - 8.5) apart from location L10 (Breweries) which recorded a mean $\mathrm{pH}$ value of $9.2 \pm 0.1$ as could be seen in Table 2 . On the contrary, during the rainy season, three sampling locations recorded $\mathrm{pH}$ values outside the permissible range. These locations were L6 (Kutimbi), L8 (Kigo) and L12 (Rigasa) with pH values of $6.4 \pm 0.1,6.3 \pm 0.1$ and $6.4 \pm 0.1$ respectively (Table $3)$. It is also revealed in Tables 2 and 3 that the rainy season had lower $\mathrm{pH}$ values than the dry season which confirm the claims of other researchers $[3,13,31]$. The slight drop in $\mathrm{pH}$ values recorded during the rainy season in all the sampling locations could be as a result of precipitation (rainfall). This is because atmospheric pollutants, particularly oxides of sulphur and nitrogen triggered by anthropogenic activities such as burning of fossil fuels (coal, oil and gas), can cause precipitation to become acidic when converted to sulphuric and nitric acids [32]. The air quality of Kaduna city had earlier been noted of having high concentrations of $\mathrm{SO}_{2}$ and $\mathrm{NO}_{2}$ [33]. Hence, the rainfall (acid rain) might have caused the drop in $\mathrm{pH}$ of the river water during the rainy season. The areas (towns) of relatively higher or lower $\mathrm{pH}$ in comparison with the river are mapped and shown in Figure 6.

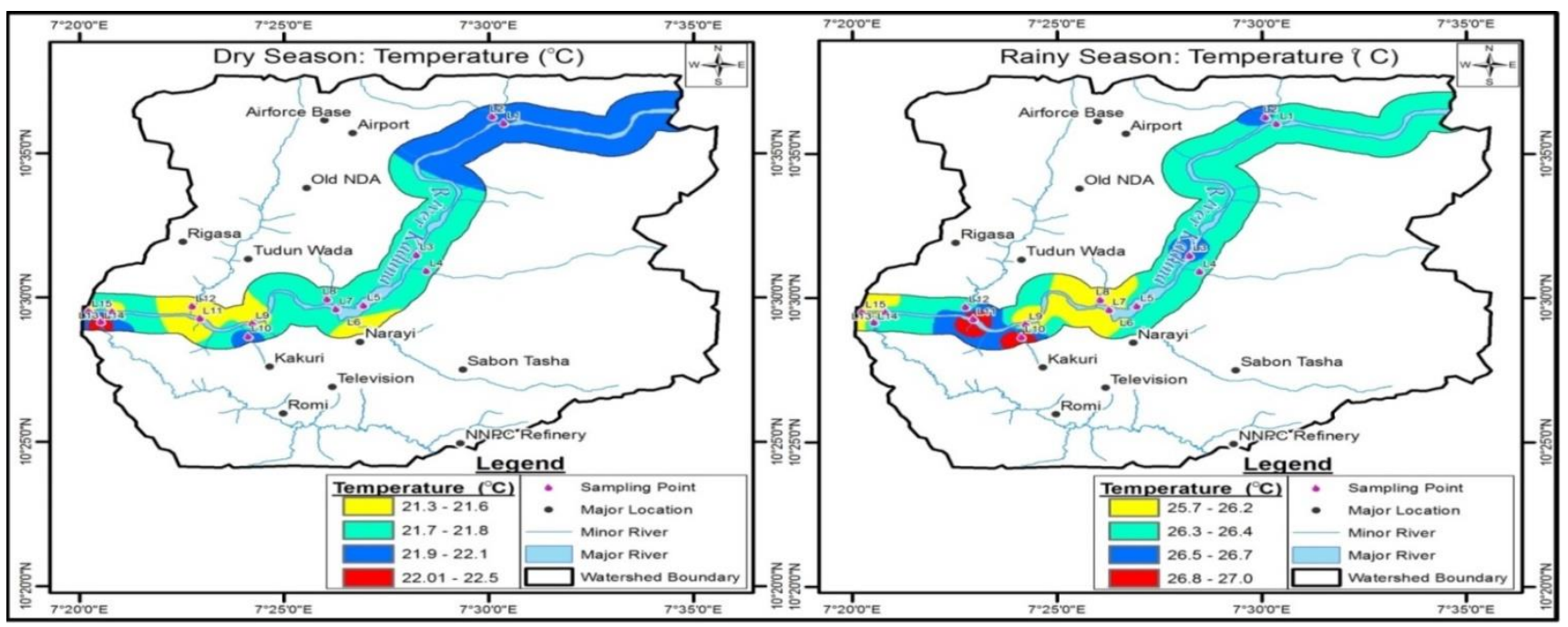

Figure 4: Water temperature map of River Kaduna

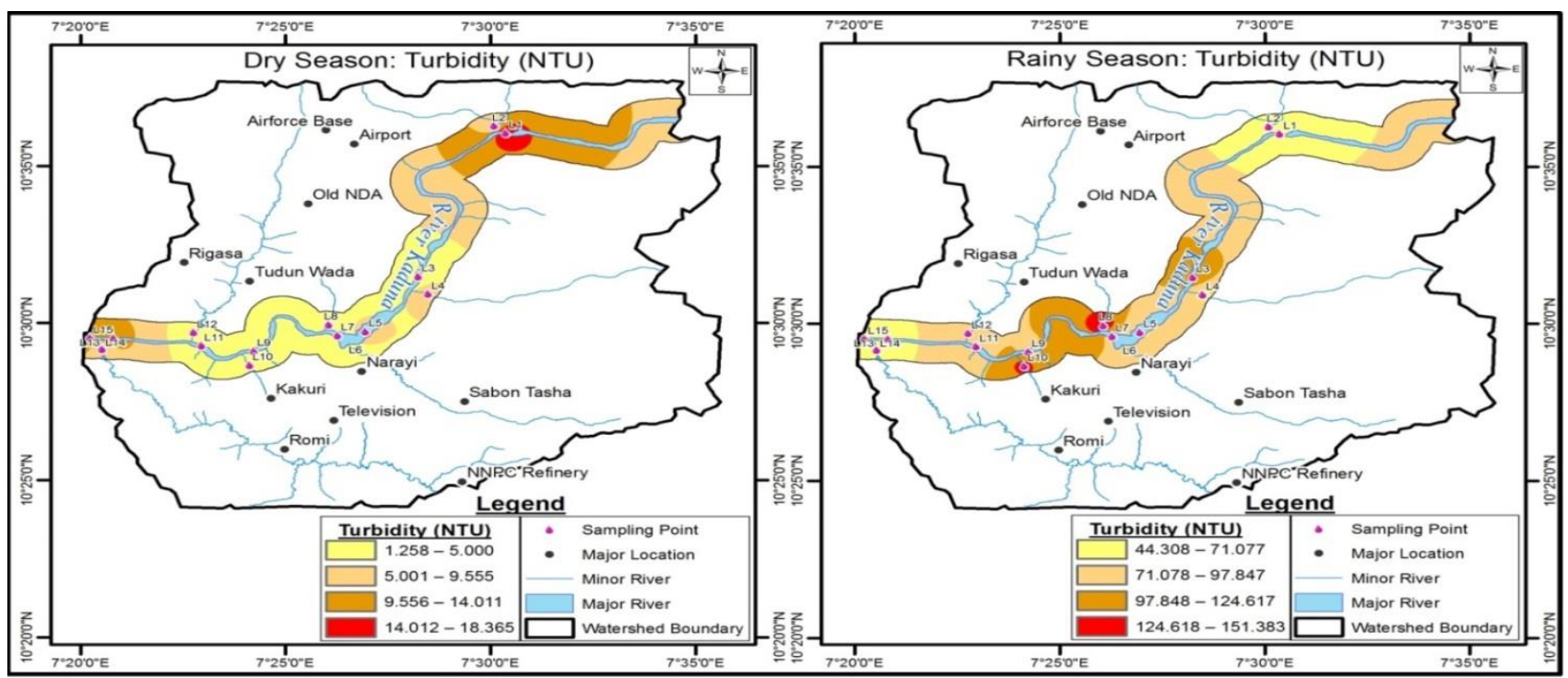

Figure 5: Turbidity map of River Kaduna 


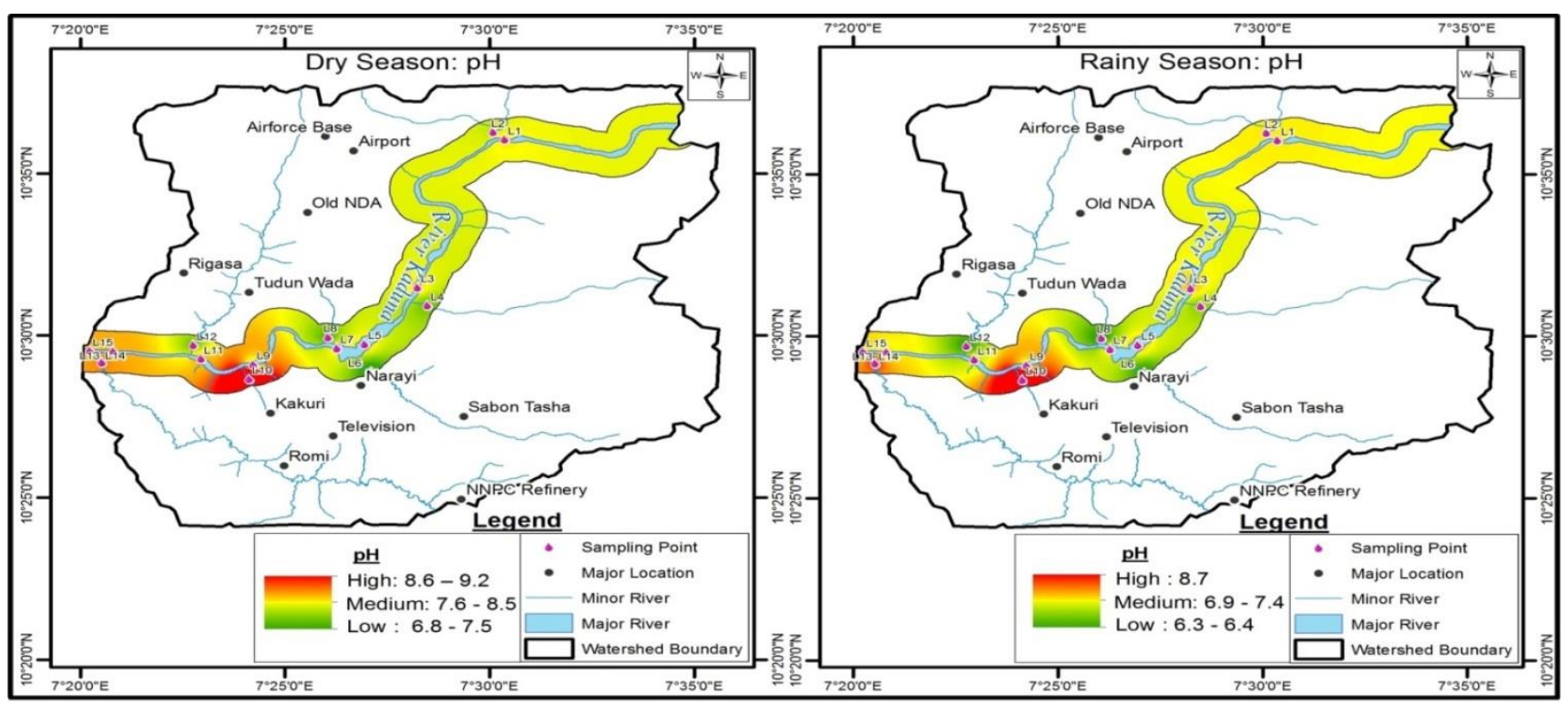

Figure 6: pH map of River Kaduna

\subsection{Dissolved Oxygen}

The minimum and maximum seasonal DO content within the monitored portion of the river were noted in the same sampling locations during both seasons. The minimum DO content noted during the dry season and rainy season was $2.76 \pm 0.01 \mathrm{mg} / \mathrm{l}$ and $3.97 \pm 0.01 \mathrm{mg} / \mathrm{l}$ respectively, occurred at sampling location L10 (Breweries) as could be seen in Tables 2 and 3 . Similarly, maximum DO content recorded during the dry and rainy season was $6.19 \pm 0.01 \mathrm{mg} / \mathrm{l}$ and $7.78 \pm 0.01 \mathrm{mg} / \mathrm{l}$, respectively and were recorded at sampling location L1 (Malali). Hence, it is obvious from Tables 2 and 3 that the DO contents of the river were higher during the rainy season. This might be caused by the obstruction of the high water current of the river during the rainy season by the presence of the numerous rocks in the river. This obstruction produced turbulence which created aeration or oxygenation of the flowing water unlike the case of water stagnation during the dry season. The lower concentration of DO observed during the dry season compared to the rainy season reaffirms the reports of other researchers earlier quoted $[3,13,20]$ but negates that of another researcher [34]. The areas and towns with low DO level are mapped and shown in Figure 7 hence, attention should be given to these areas by environmental law enforcement agents for the sake of safe guiding the river quality in terms of DO.

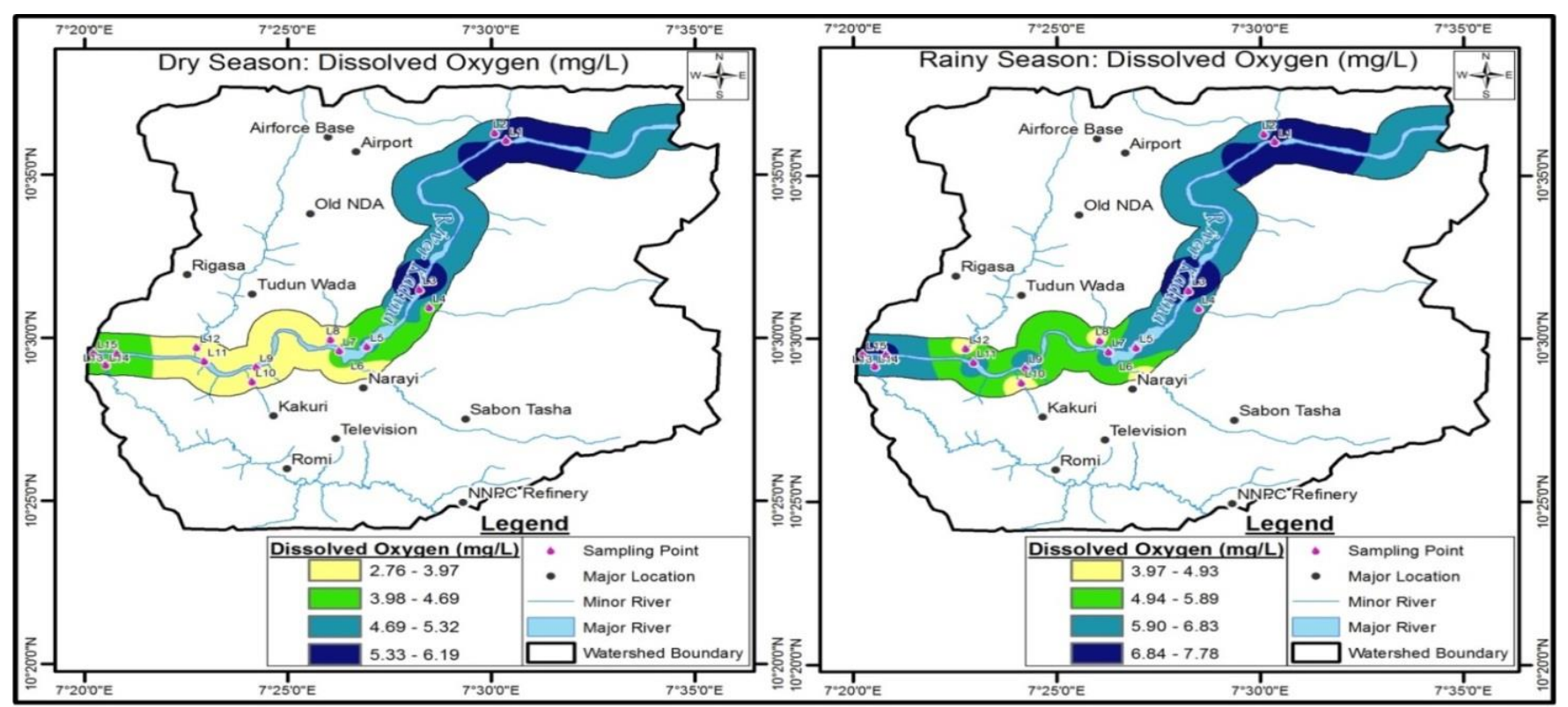

Figure 7: Dissolved oxygen map of River Kaduna 


\subsection{5-Days Biochemical Oxygen Demand}

Unlike DO, the concentrations of the 5-Day Biochemical Oxygen Demand $\left(\mathrm{BOD}_{5}\right)$ in all the sampling locations were lower during the rainy season compared to the dry season as could be seen in Tables 2 and 3. During the rainy season, the $\mathrm{BOD}_{5}$ of the entire sampling locations apart from L10 (Breweries) were within the permissible limit. This was not the case during the dry season as sampling locations L6, L7, L8, L9, L10, L11 and $\mathrm{L} 12$ recorded $\mathrm{BOD}_{5}$ concentrations higher than the permissible limit. Lower concentrations of $\mathrm{BOD}_{5}$ during the rainy season could be connected to the high DO content of the river during the rainy season as earlier explained. This synergy noted between the $\mathrm{BOD}_{5}$ and DO was also observed in similar works carried out by other researchers [13, $35-38]$. In other words, as the DO content of a given water sample increases, its $\mathrm{BOD}_{5}$ reduces and vice-versa. The mapping provided in
Figure 8 will aid environmental law enforcement agents to check the possible polluters of the river especially in areas and towns identified to be highly polluted.

\subsection{Chemical Oxygen Demand}

The Chemical Oxygen Demand (COD) in all the sampling locations were above the permissible limit $(20 \mathrm{mg} / \mathrm{l})$ irrespective of the sampling season as could be seen in Figure 9 though, COD values were higher during the dry season than the rainy season. The rainy season COD ranged from $35.34 \pm 0.1 \mathrm{mg} / \mathrm{l}$ to $61.46 \pm 0.1$ $\mathrm{mg} / \mathrm{l}$ while the values obtained during the dry season ranged from $42.50 \pm 0.1 \mathrm{mg} / \mathrm{l}$ to $74.08 \pm 0.1 \mathrm{mg} / \mathrm{l}$. The minimum and maximum values of COD during both seasons were recorded at sampling locations L15 (Railway bridge) and L8 (Kigo), respectively.

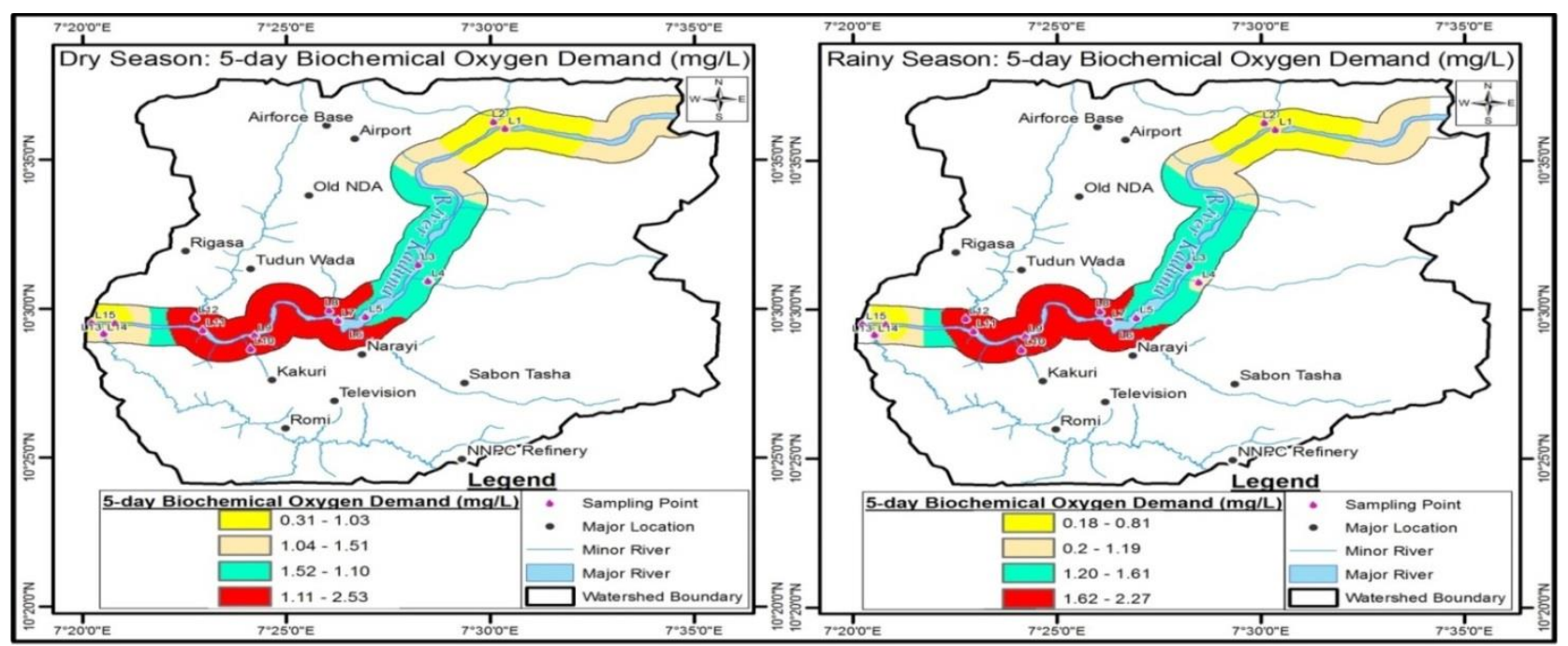

Figure 8: 5-Day Biochemical Oxygen Demand (BOD 5 ) Map of River Kaduna

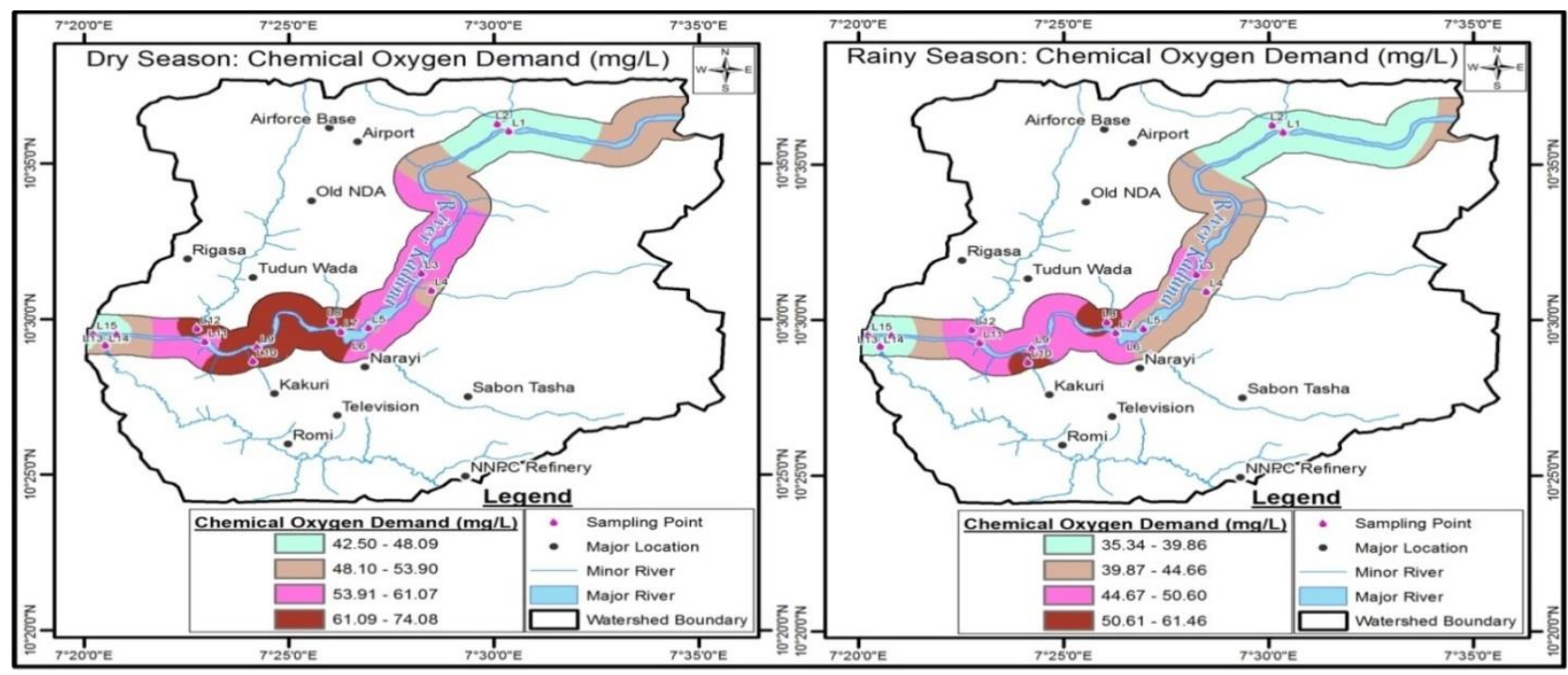

Figure 9: Chemical Oxygen Demand (COD) map of River Kaduna 
COD is a measure of the total quantity of oxygen required to oxidize all biologically active and inactive organic materials into carbon dioxide and water [39]. The quantity of oxygen needed to oxidize the biologically active organic matters corresponds to the BOD. Hence, the excessively higher concentrations of COD compared to BOD in all the sampling locations indicates that the river contains more of biologically inactive organic matters than biodegradable organic matters. This suggests that certain organic substances in the water may be toxic to the microorganisms present in the river. Also, the presence of inorganic substances in which the chemical oxidant (dichromate) reacted with, could have caused the excessively higher COD values compared to BOD [40].

The higher COD recorded during the dry season compared to the rainy season agreed with the reports of some of the literatures earlier cited [13, 36 - 38]. However, some other researchers recorded lower COD during the dry season in their studies [41, 42]. As previously stated, the COD values of the entire sampling locations irrespective of the season were found to be higher than the permissible limit. Control measures should therefore be taken by relevant authorities with more emphases at Kakuri and Tudun Wada areas or towns which showed higher level of COD relative to the other areas and towns as mapped in Figure 9.

\subsection{Total Nitrogen}

During the dry season, all the sampling locations recorded total nitrogen (TN) concentrations above the permissible limit $(1.0 \mathrm{mg} / \mathrm{l})$ ranging from $1.23 \pm 0.01$ $\mathrm{mg} / \mathrm{l}$ at location L3 (NNPC) to $1.70 \pm 0.01 \mathrm{mg} / \mathrm{l}$ at location L8 (Kigo). On the contrary, TN concentrations recorded during the rainy season were within the permissible limit in all the sampling locations. The minimum $(0.71 \pm 0.01 \mathrm{mg} / \mathrm{l})$ and maximum $(0.98 \pm 0.01$ $\mathrm{mg} / \mathrm{l}$ ) concentrations were recorded at locations L6 (Kutimbi) and L1 (Malali) respectively as could be seen in Table 3. The lower concentrations of TN during the rainy season compared to the dry season could be caused by the effect of precipitation on pollutant dilution experienced during the rainy season. In addition, during the rainy season, not all the precipitation (rainfall) on a watershed flows as surface runoff into streams and rivers. Part of the rainfall known as sub-surface runoff or interflow leached into the soil and moves laterally (without joining the water table) to the streams or rivers. However, another proportion of the rainfall known as base flow infiltrates deep into the soil and meet the water table before flowing into streams and rivers. The movement of water in this type of runoff (base flow) is very slow before joining the streams or rivers hence, base flow is also known as delayed runoff [27, 43, 44]. Nitrate $\left(\mathrm{NO}_{3}{ }^{-}\right)$in percolated water is usually caused by the oxidation of nitrogen compounds by soil bacteria and it moves freely with groundwater flow $[7,32]$. Hence, the higher values of $\mathrm{TN}$ during the dry season could also be caused by deep infiltrated waters (base flow) that were contaminated with nitrogen compounds which leached into the streams and rivers during the dry season. This observation of higher concentration of TN during the dry season compared to the rainy season had earlier been noted by other researchers [ $6,36,38,45]$. The nitrogen concentration of the entire length of the monitored river during both seasons is mapped and shown Figure 10.

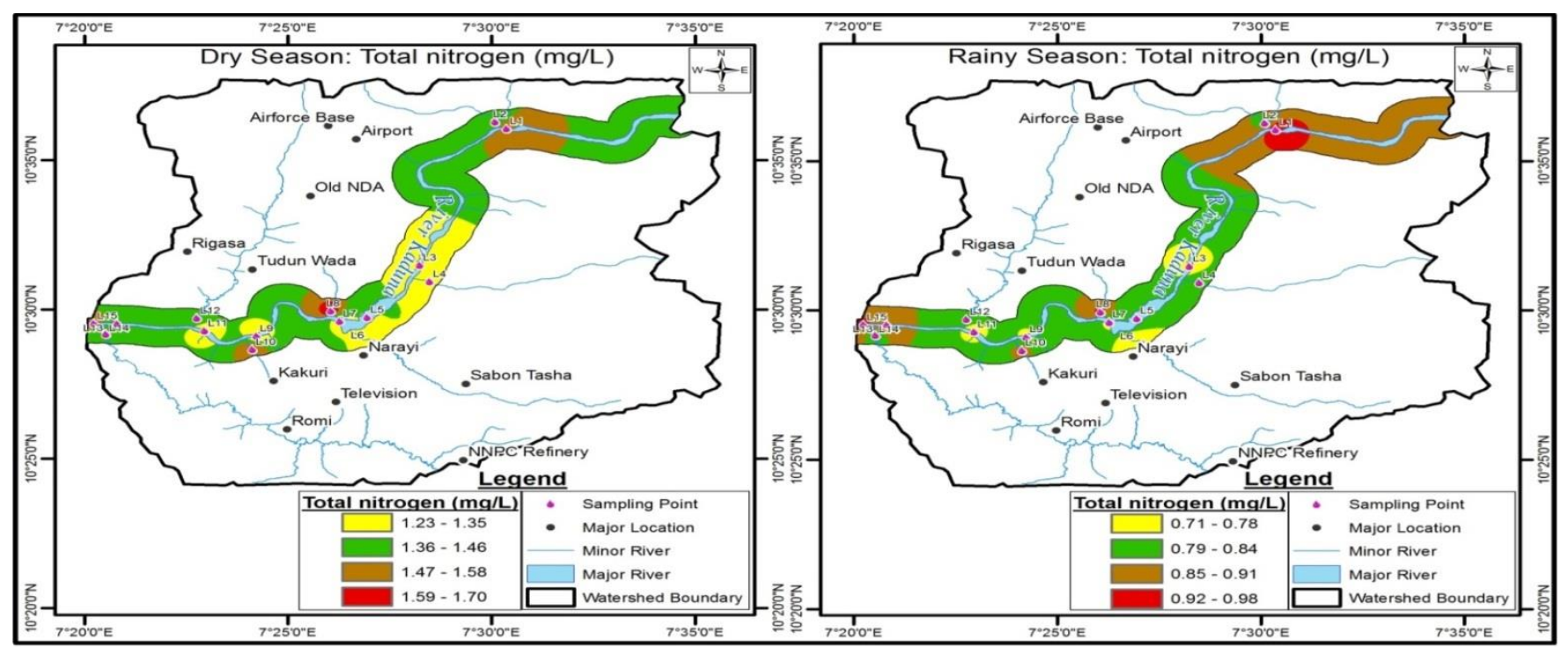

Figure 10: Total nitrogen map of River Kaduna 


\subsection{Total Phosphorus}

The total phosphorus (TP) concentrations in all the sampling locations during both seasons were above the permissible limit set by U.S. EPA (0.1 mg/l). Nevertheless, the values recorded during the dry season ranged from $0.179 \pm 0.05 \mathrm{mg} / \mathrm{l}$ to $0.234 \pm 0.05$ $\mathrm{mg} / \mathrm{l}$ while the rainy season concentrations ranged from $0.109 \pm 0.05 \mathrm{mg} / \mathrm{l}$ to $0.142 \pm 0.05 \mathrm{mg} / \mathrm{l}$. These minimum and maximum concentrations during both seasons were observed at sampling locations L3 (NNPC) and L1 (Malali), respectively. Observations of lower concentrations of TP in surface water during the rainy season compared to the dry season were also documented by some past literatures [45 - 47]. This could be caused by the same factors responsible for TN as earlier explained. Phosphorus is generally considered to be the limiting nutrient for plant growth in freshwater [46]. Hence, relevant environmental law enforcement agencies is hereby advised to check the anthropogenic activities within the watershed that could have caused the high TP concentrations recorded and then take necessary actions against polluters. This will safe guide the river from algae bloom which usually results to eutrophication. However, law enforcement agents should lay more emphasis at areas and towns that showed higher concentrations of TP as could be identified in Figure 11.

\section{CONCLUSION}

Based on the results obtained in this research, the following conclusions can be drawn: i. The water temperature of River Kaduna is within the U.S. EPA permissible limit regardless of the sampling location and season.

ii. The water quality of River Kaduna is seriously influenced by season and the quality deteriorates mostly during the dry season.

iii. COD and TP concentrations of River Kaduna are above the U.S. EPA permissible limits regardless of the sampling location and season.

\section{RECOMMENDATIONS}

Based on the conclusions above, the following measures are therefore recommended:

i. Farming at the river banks should be banned as the fertilizers used by farmers in improving the soil nutrients easily drain into the river and increase the phosphorus and COD concentrations.

ii. Relevant environmental law enforcement agencies should identify the sources of pollution in areas and towns shown to have impairment level in the water quality maps developed and then impose disciplinary measures against culprits.

\section{REFERENCES}

[1] Li, S. and Zhang, Q. Spatial Characterization of Dissolved Trace Elements and Heavy Metals in the Upper River (China) using Multivariate Statistical Techniques. Journal of Hazardous Material, 176(1): 579-588. 2013

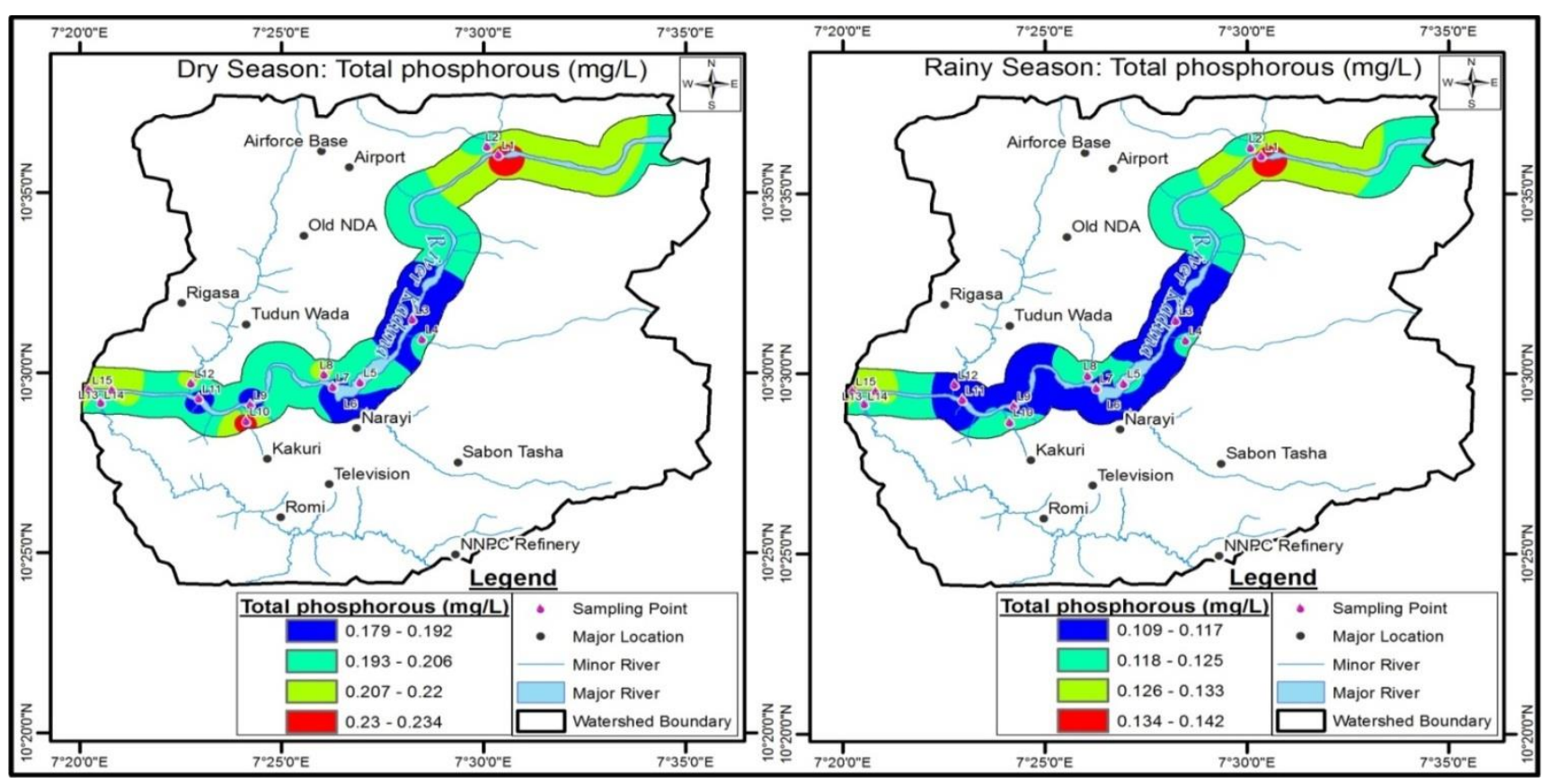

Figure 11: Total phosphorus map of River Kaduna 
[2] Pizarro, J., Vergara, P. M. and Valenzuela, A. M. Heavy Metals in Northern Chilean Rivers: Spatial Variation and Temporal Trends. Journal of Hazardous Material, 181(3): 747-754. 2015.

[3] Yusuf, R. O., Durojaiye, A. O. and Salawudeen, T. A. Pollution Monitoring Along Kaduna River. International Journal of Environmental Science, 4(4): 76-82, 2008.

[4] Ekiye, E. and Luo, Z. Water Quality Monitoring in Nigeria; Case Study of Nigeria's industrial cities. Journal of American Science, 6(4): 22-28, 2010.

[5] Jeb, D. N. and Aggarwal, S. P. Flood Inundation Hazard Modelling of the River Kaduna Using Remote Sensing and Geographic Information Systems. Journal of Applied Sciences Research, 4(12): 1822-1833, 2008.

[6] Mohammed, A. A. Water Quality Study of River Kaduna. International Journal of Advanced Research 1(7): 467-474, 2013.

[7] Musa, A. O. and Kazeem, B. Fertilizer Application Along the Banks of River Kaduna: Good for the Farmers, Bad for the Environment. International Food Program Institute (IFPRI), 11(1): 1-6, 2012.

[8] Adamu, D. M., Philip, K. and Munyale, V. 0. Assessment of Anthropogenic Activities on Water Quality of River Kaduna. Journal of Applied Science and Environmental Management, 18 (4): $629-636,2012$.

[9] Dada, F. O., Jibrin, G. M. and Ijeoma, A. Secondary Atlas. Macmillan Nigeria Publisher Ltd, 2011.

[10] Emmanuel, E., Odjadjare, O. and Anthony, I. O. Physiochemical Quality of an Urban Municipal Wastewater Effluent and its Impact on the Receiving Environment. International Journal of Environmental Monitoring and Assessment, 170(3): 383-394, 2016.

[11] Mohammed, A. E., Ibrahim, I., Badaru, Y. U., Garba, I.K. and Kudu, D. Assessment of Effluents Discharged From Textile Industries in Selected Villages in Kaduna State, Nigeria. African Journal of Environmental Science and Technology, 9(5): 385-389, 2015.

[12] Alayande, A. W. and Agunwamba, J. C. Impacts of Urbanization of Kaduna River Flooding. Journal of American Science, 6(5): 28 -35, 2010.

[13] Adebayo, 0. 0. Evaluation of Spatio-Temporal Characteristics of River Water Quality in OgunOsun River Basin in Nigeria Using Geographical Information System and Multivariate Techniques. A Ph.D Thesis submitted to the Post graduate School of University of Ibadan, Nigeria, 2014.

[14] ESRI, ArcGIS 10.5: Using ArcGIS Spatial Analyst. Software User Guide ESRI, USA, 2015.
[15] Abbas J. K. Assessment of Water Quality in Tigris River-Iraq by Using GIS Mapping. Natural Resources, 4(1): 441-448 2013.

[16] Ahmed, D. A. Geography of River Kaduna. Journal of Environmental Monitoring and Assessment, 11(4): 128-133, 2016.

[17] Saminu, A., Abdullahi, I., Tsoho, U., Nasiru, I. and Ayinla, A. I. Investigating the Hydrological Characteristics of Kaduna River Basin. International Journal of Engineering Sciences \& Research Technology, 9(2): 2420-2423. 2013.

[18] Sola, A.P. and Adeniran, J. G. Global Climatic Change and Sustainable Water Management for Energy Production in the Niger Basin of Nigeria. Earth Environ. Sci., 6(2): 4275-4283, 2015.

[19] Nigeria Population Commission (NPC)-Vol. 03, 2010.

[20] Udiba, U. U., Diya'uddeen, B. H., Inuwa, B., Ashade, N. O., Anyanwu, S. E., Meka, J. and Odeke, E. H. Industrial Pollution and its Implications for the Water Quality of River Galma: A Case Study of Dakace Industrial Layout, Zaria, Nigeria. Merit Research Journal of Environmental Science and Toxicology, 2(8): 167-175, 2014

[21] Esengul, K. Cem, T. and Arzu C. Monitoring Stream Water Quality: A Statistical Evaluation. Poland Journal of Environmental Studies. 23(5):1637-1647, 2014.

[22] Vujovic, S., Srdan, K. and Borislav, M. Application of Chemometric Technique in the Assessment of Water Quality of Tisza River (Serbia). International Virtual Conference Advanced Research in Scientific Areas, Section 10 (Natural Science): 1595-1601, 2012.

[23] Carlos, M., Alejandra, V. V., Carlos, O. and Alicia, F. C. Water Quality Index as a Tool for River Assessment in Agricultural Areas in the Pampean Plains of Argentina. Journal of Urban and Environmental Engineering, 1(1):18-25, 2007.

[24] APHA Standard Methods for Estimation of Water and Waste Water, 22 ${ }^{\text {nd }}$ Eddition. American Public Health Association, Washington, DC, 2005.

[25] U. S. EPA Parameters of Water Quality: Analysis, Interpretation and Standards. A Publication of Environmental Protection Agency, Washington DC, USA, 2001.

[26] Garg, S. K. Hydrology and Water Resources Engineering, $15^{\text {th }}$ Edition. Khanna Publichers, New-Delhi, 2010.

[27] Arora, K. R. Irrigation, Water Power and Water Resources Engineering, $5^{\text {th }}$ Edition. Standard Publishers Distributors, Delhi, 2011. 
[28] Nelkon, M. and Parker, P. Advanced Level Physics, $7^{\text {th }}$ Edition. CBS Publishers \& Distributors, New Delhi, 1995.

[29] Ogedengbe, K. and Oke, A. O. Studies on the Potential of Opeki River Dam for Water Supply and Irrigation. Moor Journal of agricultural Research.5(1): 74-81, 2015.

[30] Igboanugo, A. C., Ezemonye, L.I.N. and Chiejine, C.M. Influence of Effluent Discharge and Runoffs into Ikpoba River on its Water Quality. Nigerian Journal of Technology, 32(2): 294-303, 2013.

[31] Wogbere, E. L., Gbenga, O. O. and Randy, S. B. Sources of Low pH in Woji River, Nigeria. Journal Water Pollution Control Association. 63(7): 288305, 2013.

[32] Sawyer, C. N., McCarty, P. N. and Parking, G. F. . Chemistry for Environmental Engineering, $6^{\text {th }}$ Edition. McGraw-Hill Inc., New York, 2015.

[33] Mahmoud, A. A. and Dauda, K. Air Quality Assessment of Kaduna City Using Oak Ridge Air Quality Index. International Journal of Environmental Protection, 5(2): 207-218, 2012.

[34] Kolo, R. J. Assessment of Physico-Chemical Parameters of Shiroro Lake and its Major Tributaries. Poland Journal of Environmental Studies. 25(2): 836-850, 2015.

[35] Adedokun, T. A. and Agunwamba, J. C. Assessment of Pollution-Induced Dissolved Oxygen Variation in River Challawa. Nigerian Journal of Technology, 34(3): 616-623, 2015.

[36] Moshood, K. M. Assessment of the Water Quality of Oyun Reservoir, Offa, Nigeria: Selected PhysicoChemical Parameters. Turkish Journal of Fishery and Aquatic sciences 18(3): 709-719, 2016.

[37] Anazoo, J. J. and Ibe, S. N. Sanitary Quality of Ulasi River, Okija, Anambra State, Nigeria. African Journal of Applied Zoology and Environmental Biology. 7(2): 52-59, 2015.

[38] Adie, D. B. Multivariate Statistical Analysis of Pollution Characteristics in Rivers of the Middle
Galma Basin, Nigeria. A Ph.D Dissertation submitted to the Post graduate School of Ahmadu Bello University, Zaria, Nigeria, 2008.

[39] Russell, D. L. Practical Wastewater Treatment, $1^{\text {st }}$ Edition. John Wiley \& Sons, Inc., Hoboken, New Jersey, 2015.

[40] George, T., Franklin, L. B. and David, S. H. Wastewater Engineering, Treatment and Reuse (Metcalf \& Eddy), 4th Edition. Tata McGraw-Hill Publishing Company Limited, New-Delhi, 2004.

[41] Shrestha, S. and Kazama, F. Assessment of Surface Water Quality Using Multivariate Statistical Techniques: A case study of the Fuji River Basin Japan. Environmental Modeling and Software, 22(4): 464-475, 2015.

[42] Chaosheng, Z. Using Multivariate Analysis and GIS to Identify Pollutants and their Spatial Patterns in Urban Watersheds in Galway, Ireland. Environmental Pollution, 142(3): 501-511, 2013.

[43] Subramanya, K. Engineering Hydrology, 4th Edition. Tata McGraw Hill Publishing Company, Ltd., New Delhi, India, 2016.

[44] Suresh, R. (2013). Soil and Water Conservation Engineering, $6^{\text {th }}$ Edition. Standard Publishers Distributors, New Delhi.

[45] Biao, H., Yanfeng, Z., Xuezhend, S. and Dongsheng, Y. Source Identification and Spatial Variability of Nitrogen, Phosphorous and Selected Heavy Metals in Surface Water and sediment in the Riverine System of an Urban Interface. Journal of Environmental Science and Health, 42(3): 10801112, 2014.

[46] Nyenje, P. M., Foppen, J. W., Uhlenbrook, S., Kulabbako, R. and Muwanga, A. Eutrophication and Nutrient Release in Urban Areas of SubSaharan Africa: A Review. Science of Total Environment, 408(3): 447-455, 2016.

[47] Adebola, A. O., Seun, M. A. and Oladele, O. Water Quality Assessment of River Ogun Using Multivariate Statistical Techniques. Journal of Environmental Protection, 4(1): 466-479, 2013. 